\title{
高波による海岸堤防前面下端からの裏込材吸出量予測法の一般化 \\ Generalization of a method for predicting suction rate of backfilling materials from the front lowest edge of a coastal dike by big waves
}

\author{
五百藏政文 $^{1} \cdot$ 山本吉道 ${ }^{2} \cdot$ 大嶋義隆 $^{3}$ \\ M asafumi IOROI, Yoshimichi YAM A M OTO and Yoshitaka OSHIM A
}

\begin{abstract}
In a beach or a shallow area, there are a few cases that coastal dikes were destroyed directly by strong wave force. On the other hand, a lot of field cases show that scour and suction caused by the continuing action of waves bring their destruction gradually. Therefore, it is important for us to establish prediction methods of suction rate from within the coastal dikes. In this paper, we improve loroi et al.'s formula so that the suction rate is gotten with high accuracy by using the settling velocity of Rubey. Then, we reveal the influence of coefficient of uniformity and dry density to the suction rate using experimental data. Moreover, we examine how to get the suitable values of the flow velocity and the excess pore pressure using CADM AS-SURF, and confirm that the calculated values agreed with experimental values.
\end{abstract}

\section{1はじめに}

極浅海域や前浜に設置された海岸堤防や護岸の場合, 大 きな波力に対する力負けではなく, 波が長時間作用するこ とによる前面洗掘と裏込め材の吸出しから破壊に至る事例 が多数ある．したがって産業活動によって，海岸侵食が進 むだけでなく，地球温暖化による海面上昇など海岸環境の 悪化が深刻になりつつある現在，この洗掘量や吸出量を予 測することは極めて重要になってきた。 上記の破堤原因が 主に洗掘・吸出しによることを大河原ら（1983）などが指 摘し, 岩崎ら（1995）は堤防前面被覆に施工不良や老朽化 による隙間がなくても堤体最下端から吸出しが生じること を大型実験で示し，前野ら（2000）は矢板式単純護岸に対 して多孔質弾性体の浸透理論を用いた有限要素解析に基づ く吸出し予測を, 中村ら（2006）は捨石式単純護岸に対し てVOF-FEM改良モデルにより吸出し検討を行った。 コン クリート被覆の三面張り堤防や二面張り護岸に対しては, 山本ら（2009）が前面水深3 m以浅ならば洗堀・吸出しに よる被災が卓越することを被災事例検討と安定計算から示 し, 山本ら（2011）が同構造物の破壊を越波量と正味の有 効せん断抵抗力（有効せん断抵抗力とせん断力の差）で判 別できることを提案し, さらに, 山本ら（2012）は同構造 物の破壞程度を判別するために予め必要となる前面洗掘量 算定図を提案すると共に, 裏込妃粒径が大きくなるほど, 正味の有効せん断抵抗力が大きくなることを明らかにし た．しかし，粒径の大小に拘らず，堤体前面の砂層厚が洗 掘によって非常に薄くなるにつれて, 正味の有効せん断抵 抗力は負の值になる。 そして, 裏込め材粒径が小さな砂の

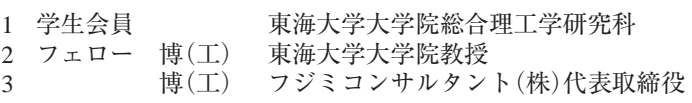

場合は, 粒子の移動抵抗力が小さいため, 直ちに吸出しに 繋がるが，裏込め材粒径が大きくなってくると，粒子の移 動抵抗力も大きくなってくるため, 直ぐの吸出しには繋が らない，すなわち，吸出しのより正確な評価のためには， このことを考慮した吸出量算定式の構築が必要であり， 五百藏ら（2012）が堤防前面下端からの裏込め材の吸出量 算定式を提案し, 実験スケールと現地での適用性について 確認した。本研究では，五百藏ら（2012）が提案した吸出 量算定式をより使い易いものに改良すると共に，堤防裏込 め材の均等係数と乾燥密度の違いが吸出量に及ぼす影響を 明らかにする.ささらに, 将来の三次元予測法開発のために, 多孔質体内の流体運動を数值計算できるCADMAS- SURF （沿岸技術研究センター, 2008）から戻り流れの圧力と流 速を求め, 本算定式から吸出量を算定する方法の適用性に ついても検討する.

\section{2.吸出し実験}

\section{（1）実験装置}

図-1に示すように幅 $0.5 \mathrm{~m} \times$ 高さ $0.8 \mathrm{~m} \times$ 全長 $22 \mathrm{~m}$ の二次元 造波装置に砂層と表法コンクリート被覆, 天端と裏法ア クリル板被覆の堤防模型を設置し, 表法根本の矢板から $1.6 \mathrm{~cm}$ 離して間隙水圧計を岸向きと沖向きに2台設置し吸 出し実験を行った。

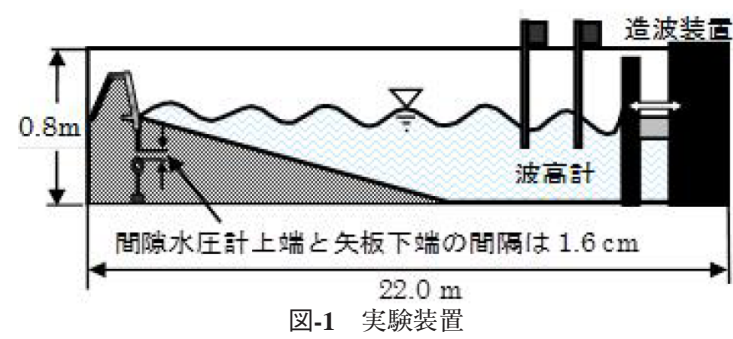




\section{（2）実験方法}

\section{a) 再現実験}

典型的な高波災害事例である平成 9 年台風9号による静 岡県広野海岸堤防の吸出しでの破堤を再現しこの実験法 での妥当性を確認した．高波に対する本水路の寸法上の 制約から模型スケール1/30とし，フルード則を用いて被 災時の暴風期来襲波である有義波高 $22.33 \mathrm{~cm}$ ，有義周期 $2.65 \mathrm{~s}$ の不規則波を 2 時間入射させた，砂浜と裏込め材の 粒径は，現地海岸の底質粒径が主に0.5 1.0mm程度の細 粒分と2 3mm程度の粗粒分から成り立っており，伊藤 · 土屋の底質に関する相似則（1985）を当てはめると，底 質粒径の縮小スケールは1/3となるので, $0.2 \mathrm{~mm}$ と $0.66 \mathrm{~mm}$ の砂を2：1で混ぜ合わせた混合砂を用いた.

\section{b) ケース1 4}

再現実験と同様の実験条件で，表-1に示す実験ケース を複数回実施した。

表-1 実験ケースと中央粒径, 均等係数, 乾燥密度の関係

\begin{tabular}{c|c|c|c}
\hline 実験ケース & 中央粒径 & 均等係数 & 乾燥密度 \\
\hline ケース 1 & $0.2 \mathrm{~mm}$ 砂 & 1.56 & $(*)$ \\
\hline ケース 2 & $0.2 \mathrm{~mm}$ 砂 & 9.8 & $(*)$ \\
\hline ケース3 & $0.2 \mathrm{~mm}$ 砂 & 20.1 & $1.55\left(\mathrm{~g} / \mathrm{cm}^{3}\right)$ \\
\hline ケース4 & $0.2 \mathrm{~mm}$ 砂 & 20.1 & $1.81\left(\mathrm{~g} / \mathrm{cm}^{3}\right)$ \\
\hline
\end{tabular}

*ケース1，2についての乾燥密度は計測してないがケース3と同 じように堤防の施工をおこなった。

\section{(3) 実験結果}

図-2はケース1における実験結果である。本図に示され るように波が作用し始めると前面洗掘が始まり，開始40 分頃には前面洗掘が矢板下端まで進み, 砂の吸出しが無 視できなくなってきた。 それにより堤体内部の砂が矢板 下端から外側へ移動し, 堤体内の上部の空隙が大きく なってきた．2時間後には堤体内の2/3の砂が矢板下端か ら吸出され破堤寸前となった。

図-3はケース2，3の実験結果で，ケース1では堤体内の 下部の砂が吸出されると上部の砂が下部へすぐに移動し吸 出されるのに対して，ケース2，3では堤体内の下部の砂が 吸出されても上部の砂は下部へすぐに移動せず，数十分程 度経過してから下部へ移動し吸出されていた。本ケースの 実験から, 中央粒径が同じでも，均等係数が大きくなるほ ど，累積吸出量が小さくなることを確認できた.

図-4はケース3，4の実験結果で，乾燥密度の大きい ケース4の方が, 上部の砂は下部へすぐに移動せずに吸 出されなくなっていた。 その結果, 同じ経過時間に対し て累積吸出量が小さくなることが確認できたので，堤体 毫込め材の乾燥密度を大きくすることによって, 吸出し を遅らせることが期待できる。ただし，乾燥密度に違い があっても，最終の累積吸出量はほぼ同じであった.

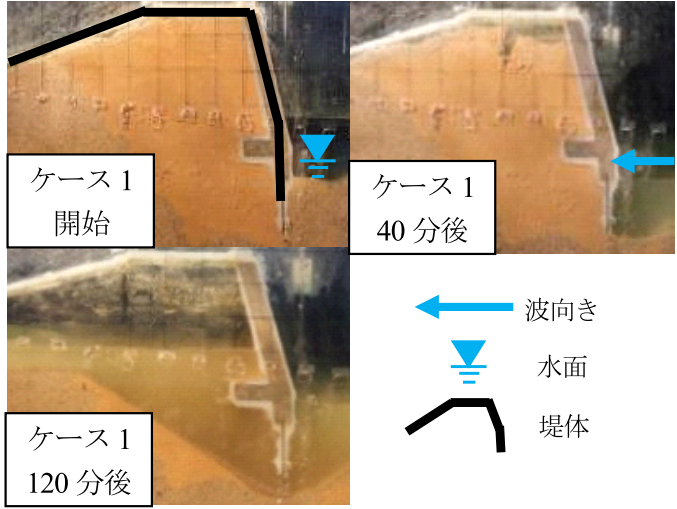

図-2 ケース1の吸出し状況

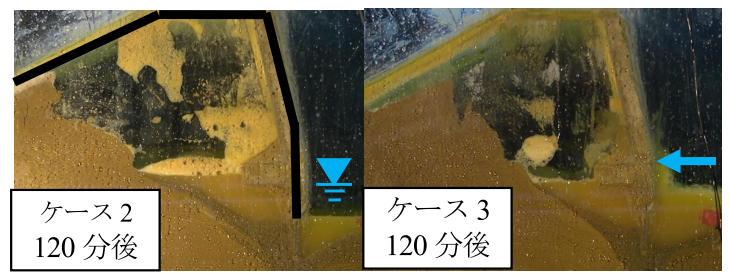

図-3 ケース2と3の吸出し状況の比較

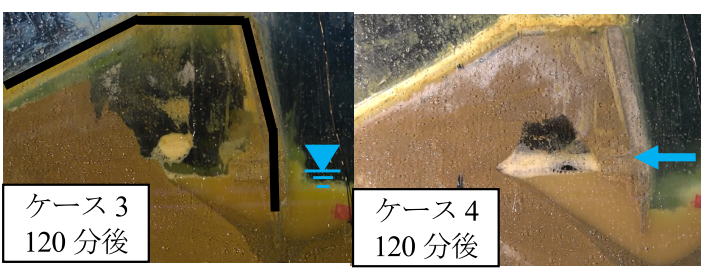

図-4 ケース3と4の吸出し状況の比較

\section{3. 理論的考察}

\section{（1）裏込め材の吸出量算定式の改良}

五百藏ら（2012）が提案した吸出量算定式について以 下に概説する：

裏込め材の吸出量は最大吸出し力と有効吸出し抵抗力と の差に比例すると考え, 堤体下端吸出し口における有効 吸出し抵抗力は式（1）で, 最大吸出し力は式（2）で定 義した。

$$
\begin{aligned}
& \tau_{r}=\left(\rho_{s} g d_{t}-\rho_{w} g d_{t}-P_{o b \max }\right) \tan \phi \\
& \tau_{f}=0.5 f \rho_{w} V_{\max }{ }^{2} \ldots \ldots \ldots \ldots \ldots \ldots \ldots \ldots \ldots \ldots \ldots \ldots \ldots \ldots \ldots \ldots \ldots \ldots
\end{aligned}
$$

ここで, $\rho_{\mathrm{s}}$ は砂層の密度, $\rho_{\mathrm{w}}$ は海水の密度, $\mathrm{g}$ は重力加 速度, $\phi$ は前面砂層部での内部摩擦角 ( 出面での流体力係数 $(\fallingdotseq 1), \mathrm{d}_{\mathrm{t}}$ は前面砂層厚 $(=$ 前面地 盤高－堤体前面下端位置）である. $P_{0 b \max }$ と $V_{\max }$ は戻り 流れの堤体前面下端での最大過剩間隙水圧と最大流速 で，各々，式（3）と式（4）から求められる。 


$$
\begin{aligned}
& \left.\begin{array}{l}
P_{o b \max } / \rho_{w} g H=a \tanh \left(0.03 H / d_{t}\right)^{b} \\
a=0.37\left(0.2 / D_{50}\right)^{0.85}+0.30 \\
b=0.55\left(0.2 / D_{50}\right)^{0.78}+0.05
\end{array}\right\} \\
& V_{\text {max }}=\sqrt{2\left(P_{o b \max } / \rho_{w}\right)(h / H+1.0)^{-1.11}}
\end{aligned}
$$

ここで，H は堤体前面での入射有義波高， $D_{50}$ は中央粒 径, h は吸出し口までの堤体前面水深である.

これらの最大吸出し力と有効吸出し抵抗力について, 無次元化のため, 各々, 式（5）と式（6）で表される無 次元吸出し力 $\theta$ と無次元限界吸出し力 $\theta_{c}$ に置き換える.

$$
\begin{aligned}
& \theta=\tau_{f} /\left(\rho_{s}-\rho_{w}\right) g D_{50} \\
& \theta_{c}=\tau_{r} /\left(\rho_{s}-\rho_{w}\right) g D_{50}
\end{aligned}
$$

また，図-5は吸出し実験（沖波の有義波高 $\mathrm{H}=22.33 \mathrm{~cm}$, 周期T =2.65s） でOHPフィルムに描いた格子の数をビデオ 映像から読取り粒径毎の裏込め材の累積吸出量 $\mathrm{Q}\left(\mathrm{m}^{2}\right)$ の 経時変化を示した図であるが，本図から粒径が小さくな るにつれて，累積吸出量が大きくなり，時間が経過する とともに単位時間当りの吸出し量が低下していくことが 分かる。この単位時間当りの吸出量の経時変化を考慮す れば，堤体前面下端の単位幅・単位時間当りの吸出量q $\left(\mathrm{m}^{2} / \mathrm{s}\right)$ は式（7）で表される.

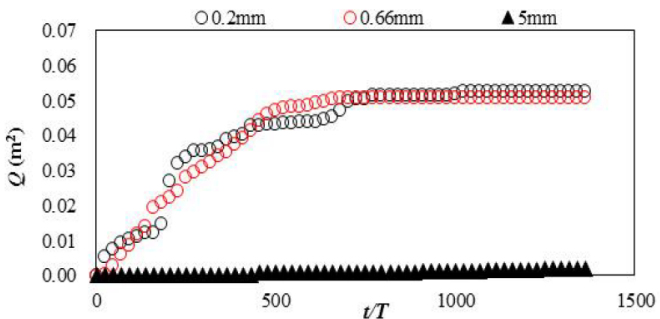

図-5 累積吸出量と経過時間の関係

$$
q \propto\left(\theta-\theta_{c}\right) \frac{1}{2}\left(1+\cos \left(\frac{\alpha t}{T}\right)\right) \quad\left[0<\frac{\alpha t}{T}<\pi\right]
$$

$$
\left.\begin{array}{l}
\alpha=-9.0 \times 10^{-5}\left(D_{50} / 0.2 \mathrm{~mm}\right)+0.0031\left[1 \leq D_{50} / 0.2 \mathrm{~mm} \leq 25\right] \\
\alpha=-3.39 \times 10^{-5}\left(D_{50} / 0.2 \mathrm{~mm}\right)+0.0017\left[25 \leq D_{50} / 0.2 \mathrm{~mm} \leq 50\right]
\end{array}\right\}
$$

ここで， T は入射波周期（s)， t は経過時間（s）， $\alpha$ は経 過時間と共に低減する程度を表す係数で，実験データか ら式（8）のようになった。

吸出量q $\left(\mathrm{m}^{2} / \mathrm{s}\right)$ を中央粒径 $\mathrm{D}_{50}(\mathrm{~m})$ と沈降速度 $\mathrm{w}(\mathrm{m} /$ s）を用い無次元化し，比例係数 $\beta$ を用いると，式（7） から単位幅・単位時間当りの吸出量を求めるための算定 式（9）を得る.

$$
\frac{q}{w D_{50}}=\beta\left(\theta-\theta_{c}\right) \frac{1}{2}\left(1+\cos \left(\frac{\alpha t}{T}\right)\right)
$$

以上が五百藏ら（2012）の算定式の概要であるが，式 （9）に含まれる裏込め材の沈降速度Wは計算法によって 大きく異なってくるため, 本研究では次の改良を加えた：

まず，沈降速度を常にRubeyの式から求めるようにし， その場合に精度の良い吸出量を算定出来るように，実験 データを整理し直して得られた比例係数 $\beta$ をグラフ化し た図-6から，係数 $\beta$ を表す図-6の実線である新しい実験式 （10）を提案する.

$$
\beta=0.028 e^{-0.35\left(D_{50} / 0.2 \mathrm{~mm}\right)}\left[1 \leq \frac{D_{50}}{0.2 \mathrm{~mm}} \leq 50\right]
$$

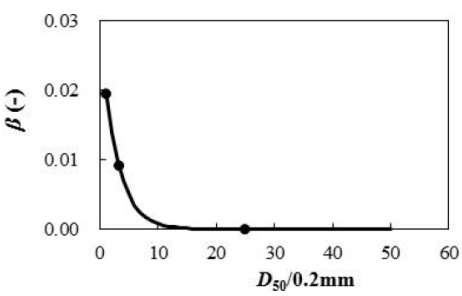

図-6比例係数 $\beta$ と粒径の関係

\section{(2) 再現計算}

\section{a) 実験ケースとの比較}

吸出量の実験值と式（9）（10）を用いた計算值との 比較を図-7に示す。ここで，入射有義波高は $22.33 \mathrm{~cm}$ ，入 射周期は2.65sである。本図から改良した算定式による計 算值が実験結果を良く再現していることが分かる.

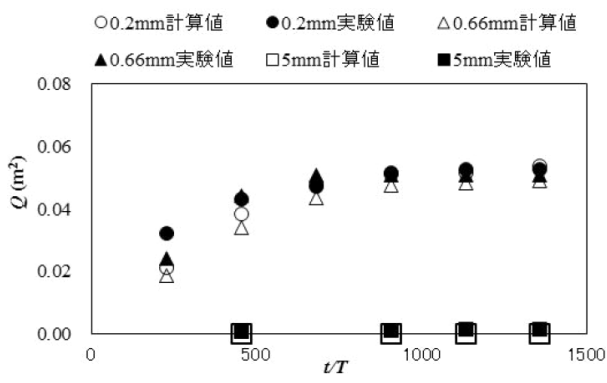

図-7 吸出量の計算值と実験值の経時変化

\section{b) 現地事例との比較}

改良した算定式を高波災害事例に適用し，対象海岸名， 外力条件などを以下に記す。

-1968年台風4号駿河海岸大井工区，沖波有義波高 $3.50 \mathrm{~m}$ ，周期13.9s，作用時間12時間.

-1982年台風18号静岡海岸南部, 沖波有義波高7.62m, 周期12.9s, 作用時間12時間.

-1991年台風9号高知海岸長浜区, 沖波有義波高3.89m, 
周期10.0s，作用時間12時間.

吸出量の計算結果と実測值との比較を図-8に示す，本 四より，改良した算定式による計算值と実測値の相関は 覀くなく，他に適当な算定式がない現時点では有用な算

・静岡海岸 ○駿河海岸、高知海岸

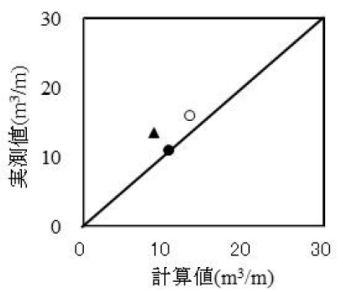

図-8 実測値と計算值との相関

定式を提案できたと判断できる.

\section{4. 均等係数と乾燥密度が吸出しに及ぼす影響}

\section{（1）均等係数が吸出しに及ぼす影響}

図-9は中央粒径が約 $0.2 \mathrm{~mm}$ で裏込め材の均等係数を変 化させ，吸出し実験のビデオ映像から読取った累積吸出 量の経時変化図である.この図より均等係数が大きくなる ほど吸出量が減少することが分かる.

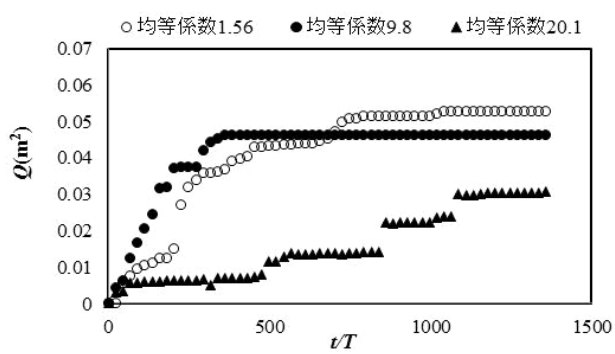

図-9 累積吸出量と経過時間の関係

吸出しの支配因子である戻り流れの過剩間隙水圧は, 先行する不規則波の影響を強く受けるため，各入射波毎 に大きくばらつくものの, その最大值で強い吸出しが生 じ破壊につながるため, 図-10で均等係数毎に縦軸の最大 值で包絡線を引いている. 本図は裏込材の均等係数を変 えて, 戻り流れ時の過剩間隙水圧 $\mathrm{P}_{\mathrm{ob}}$ と砂層厚 $\mathrm{d}_{\mathrm{t}}$ の関係を 表した図であり，前面砂層厚が薄い場合に，均等係数が 大きくなるほど，過剩間隙水圧が小さくなることが分か り，均等係数の違いを考慮した戻り流れ時の過剩間隙水 圧の最大值 $\mathrm{P}_{\mathrm{obmax}}$ 求めるための式 (11) を新たに提案する. ここで，Uは均等係数である.

図-11は，均等係数が異なる場合の累積吸出量の実験值 と均等係数を考慮した式（11）より吸出しの重要変数で ある戻り流れ時の過剰間隙水圧 $P_{0 b m a x}$ を求め, 式 (9)， （10）の吸出量算定式による計算值との比較であり，均 等係数の違いをある程度評価出来ることが分かった.

$$
\left.\begin{array}{l}
P_{o b \max } / \rho_{w} g H=a e \tanh \left(0.03 H / d_{t}\right)^{b i} \\
a=0.37\left(0.2 / D_{50}\right)^{0.85}+0.30 \\
b=0.55\left(0.2 / D_{50}\right)^{0.78}+0.05 \\
e=-0.035\left(U_{r} / U_{1.56}\right)+1.03 \\
i=-0.056\left(U_{r} / U_{1.56}\right)+1.01
\end{array}\right\}
$$

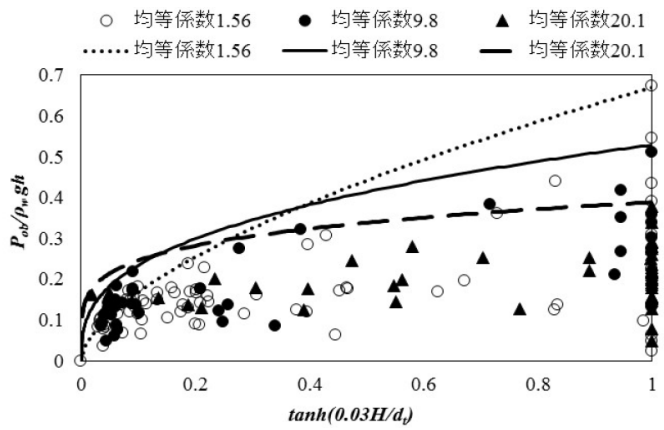

図-10 無次元砂層厚と戻り流れの過剩間隙水圧の関係

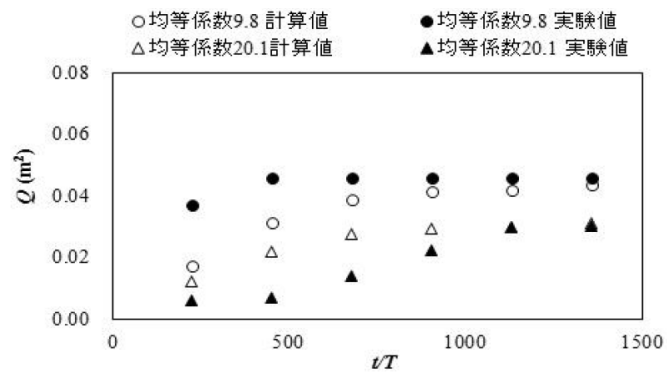

図-11 均等係数を考慮した吸出量の実験値と計算值

\section{（2）乾燥密度が吸出しに及ぼす影響}

図-12 は累積吸出量について, 本実験での乾燥密度が $1.55 \mathrm{~g} / \mathrm{cm}^{3}$ と $1.81 \mathrm{~g} / \mathrm{cm}^{3}$ の比較例である. 本図から, 乾燥密 度が大きいと, 累積吸出量の最終值はあまり変化しない が, 累積吸出量が最終值に近づくまでの経過時間が延び ることが分かった。

乾燥密度 1.55 均等係数 20.1 ・乾燥密度 1.81 均等係数 20.1

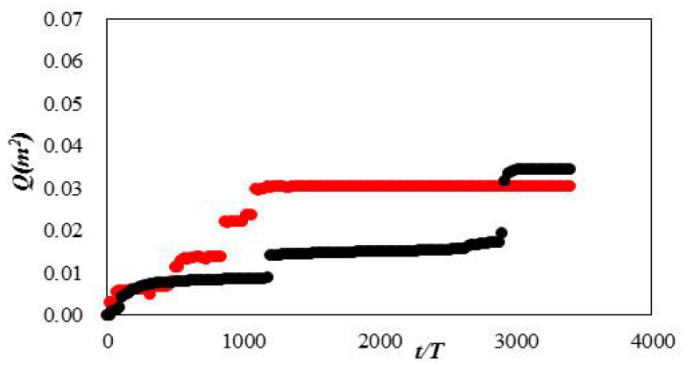

図-12 累積吸出量と経過時間の関係 


\section{CADMAS-SURFによるシミュレーション方法}

\section{（1）CADMAS-SURFを用いた吸出量の計算方法}

将来の三次元化のために, CADMAS-SURF（本数值モ デルの詳細は参考文献に記す図書を参照のこと）を用い て, 堤防前面下端の戻り流れの過剰間隙水圧と流速を求 め，算定式（5），(6)，(8)，(9），(10）に代入して吸出 量を算出することも試みた。その際に，数值実験による 計算結果から, 吸出量算定式へ代入する戻り流れ時の過 剰間隙水圧と流速の適切な位置を決定する必要があり, 予備数值実験を試みた。 その結果, 戻り流れ時の過剰間 隙水圧と流速は堤防矢板下端から下に1メッシュ, 堤体内 に3メッシュの位置が適切であることが分かった.ここで, 1メッシュは水平方向に $0.02 \mathrm{~m}$, 鉛直方向に0.01mである.

\section{(2) 数値実験結果}

空隙率が0.4（砂層や小石層の場合）のときの CADMAS-SURFを用いた数值実験結果から過剩間隙水圧 と流速を求め，算定式（5）～（10）に代入して吸出量 を算定した結果を図-13に示す。本図から，計算結果が実 験值と概ね合っているが, 全てを実験式から求めた図-7 と比べて, その計算精度は悪くなっている.この原因は, 2008年時点のCADMAS-SURFでは粒径の違いを考慮でき ないのに拘わらず，実際には図-14に示すように，粒径が 変わると圧力と流速も変化しているからである．粒径の 違いによる圧力と流速の変化を考慮することが今後の課 題である.

\section{（3）空隙率と乾燥密度の影響}

前途の水理模型実験と同様の条件で, 堤体内の空隙率 を変えた数值実験を行った。図-15より空隙率を下げると 圧力は高くなり本数值実験では吸出し量は増加するが, 図-12の乾燥密度を大きくして空隙率を下げると吸出し量 は減少している，この原因は乾燥密度が大きくなること により裏込め材のかみ合わせが良くなるからと推定でき る.さらに, 図-12の乾燥密度が大きい実験ケースにおい て空隙率が時間と共に上がってくると吸出量が急激に増 加する. したがって，空隙率の経時変化をこのモデルに 組み込むことも今後の課題である.

\section{6. 主要な結論}

（1）極浅海域や前浜に設置された三面張り堤防や二面 張り護岸の前面下端からの裏込材吸出量をより簡便に算 定できる式を提案できた。

（2）均等係数と乾燥密度の違いが吸出量に及ぼす影響 を明らかにし，均等係数の違いを吸出量算定式に組达む ことができた.

（3）CADMAS-SURF から圧力と流速を求め，それを吸
出量算定式に代入する方法に，改良すべき課題が残るも のの，十分な適用性のあることが分かった.

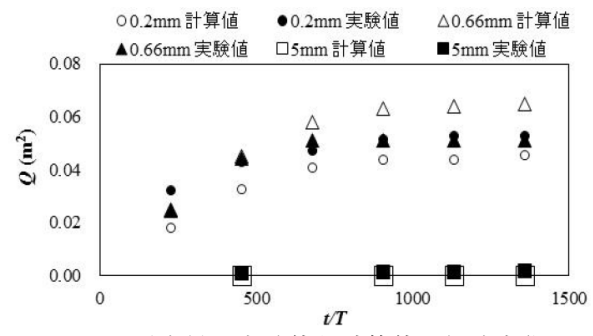

図-13 吸出量の実験値と計算値の経時変化
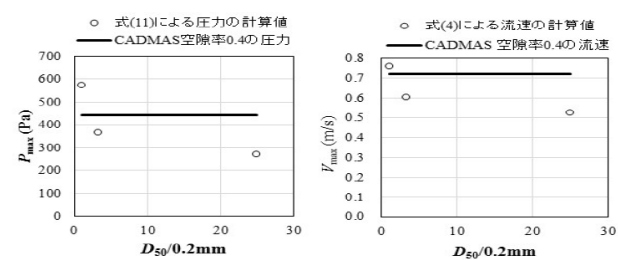

図-14 戻り流れ時の圧力, 流速の式(11) と式(4)による計算值 と数值実験による值との比較
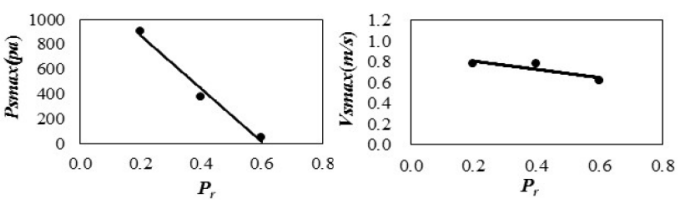

図-15 数值実験の圧力, 流速と空隙率の関係

\section{参 考 文 献}

大河原 満・斉藤雄三郎・橋本 宏 (1983)：被災事例から見た 海岸堤防・護岸に関する一考察, 第30回海講, pp. 264268.

岩崎複久 · 小谷裕司 - 佐藤憤司 - 田中茂信 $\cdot$ 名合宏之・前野 詩朗 (1995)：海岸堤防の空洞化発生機構に関する実験的 研究, 海工論文集第42巻, pp.1026-1030.

小谷裕司・星山知恵・前野詩朗 $(2000)$ : 変動水圧場における 護岸裏込め土砂の流失限界に関する研究, 海工論文集第 47巻, pp.926-930.

許 東秀・中村友昭・水谷法美 (2006) : 捨石護岸背後の埋立 土砂の吸い出し機構, 土木学会論文集B, Vol.62-N 0.1, pp.150-162.

南 宣孝・山本吉道（2009）：高波による海岸堤防破壊メカニ ズムの実験的研究, 土木学会論文集B2, Vol.65-No. 1, pp.901-905.

成吉兼二・比嘉了規・山本吉道（2011）：海岸堤防・護岸の被 災限界の研究, 土木学会論文集 B3, Vol. 67-No. 2, pp. I-100 - I-105.

五百藏政文・比嘉了規・山本吉道（2012）：海岸堤防・護岸の 高波による被害予測の研究，土木学会論文集B3，(海洋開 発) , Vol.68,N 0.2,I-882-I-887.

五百藏政文・山本吉道（2012）：高波による海岸堤防前面下端 からの裏込材吸出量算定式の提案, 土木学会論文集B 2, Vol.68,N 0,2,I-869-I-900.

沿岸技術研究センター（2008）：CADMAS-SURF実務計算事例 集，沿岸技術ライブラリーN o.30、306p.

伊藤政博・土屋義人 (1985)：二次元海浜変形の相似則につい て，土木学会論文集，第357号／II-3, pp.177-186. 